\title{
IMPLEMENTASI SINGLE PRESENCE POLICY (SPP) BAGI DUNIA PERBANKAN DALAM PERSPEKTIF UNDANG UNDANG NOMOR TAHUN 2007 TENTANG PERSEROAN TERBATAS
}

\author{
Pujiyono
}

Abstract

The objectives of this research are to know the implementation of Single Presence Policy for Banking in the Law number $40^{\text {th }}$ of 2007 about Limited Company (The Law of Limited Company) perspective and to know the supporting and resisting factors in implementation of Single Presence Policy for Banking in The Law of Limited Company perspective.

The datas consist of primary and secondary data. The primary data is collected by interview. The secondary data is collected by documentary research. Bank Indonesia region of Surakarta is chosen because its rule as supervisor and builder public bank asspecially at Surakarta region.

The result of this research shows that the implementation of single presence policy is causing : inquietable at state banking with tree options are offered by government, labour problems and the problem about legal owner and beneciary owner.

The supporting factor in the implementation of Single Presence Policy for world banking in The Law of Limited Company perspective are : It as media to increase the competitive ratio of Government Bank and it as a tool to gives limitation the domination of private bank by foreign owner. The resisting factors in implementation of Single Presence Policy for world banking in The Law of Limited Company perspective are: The law problems, the collision of the Single Presence Policy and the RUPS system in The Law of Limited Company about Single Presence Policy, The accomplishment of minimum core capital, The insiding of PBI no 8/16/PBI/2006 about Single Ownership of Indonesian Banking to Minority Shareholders, and the difficult of applying holding company at Government bank.

Keywords : Implementation, , Single Presence Policy, Banking, Limited Company

\section{A. Pendahuluan}

Proses liberalisasi sektor jasa perbankan dimulai sejak diratifikasinya General Agreement on Trade in Service (GATS). Kesempatan investor asing semakin luas sejak UU No 10 Tahun 1998 yang merevisi UU No 7 Tahun 1992 tentang perbankan memberikan akses kepada pihak asing untuk dapat memiliki bank umum melalui tiga cara yaitu pendirian bank baru, pembelian saham bank umum, dan pedirian kantor cabang atau perwakilan. Peraturan Pemerintah (PP) Nomor 29 tahun 1999 tentang Pembelian Saham Bank Umum dan Peraturan
Bank Indonesia (PBI) Nomor 2/27/PBI/2000 tentang bank umum menyatakan bahwa maksimum kepemilikan saham bank umum adalah $99 \%$. Hal tersebut diperkuat dengan Paket kebijakan oktober 2006 yang dikenal dengan Pakto 2006 adalah kebijakan mengenai Single Presence Policy yang tertuang dalam Peraturan Bank Indonesia (PBI) No 8/16/PBI 2006, juncto kebijakan mengenai pemberian insentif dalam rangka konsolidasi perbankan sebagaimana diatur dalam PBI Nomor 8/17/PBI/2006 dan dirubah dengan PBI Nomor 9/12/PBI/2007. 
Kebijakan kepemilikan tunggal Perbankan merupakan salah satu rangkaian upaya Bank Indonesia dalam menegakkan Pilar I Arsitektur Perbankan Indonesia (API), yaitu Penguatan Struktur Perbankan Nasional dan Pilar III API yaitu Peningkatan Fungsi Pengawasan. Kebijakan ini mengaharuskan kepada seluruh pemilik bank khususnya pemegang saham pengendali (PSP) untuk mengkonsolidasikan kepemilikanya di bank-bank yang dalam satu grup usahanya. Bank Indonesia menawarkan tiga opsi melalui kebijakan tersebut yaitu, divestasi saham, merger atau konsolidasi, dan pembentukan perusahaan induk di bidang perbankan (holding company) dengan tujuan untuk mereduksi jumlah bank yang saat ini berjumlah 131 bank (Johanes Ibrahim, 2008 : 2).

Kebijakan kepemilikan tunggal perbankan yang digulirkan oleh bank Indonesia dalam rangka menegakan Pilar I API, Apabila ditinjau dari sisi kepemilikan saham dan kaitannya terhadap syarat pendirian sebuah perseroan terbatas tentu bertolak belakang dengan ketentuan dalam Undang-Undang Nomor 40 Tahun 2007 tentang Perseroan Terbatas (UU PT) khususnya Pasal 7 ayat (1) yang menyatakan "Perseroan didirikan oleh 2 (dua) orang atau lebih dengan akta notaris yang dibuat dalam bahasa Indonesia" Sesuai ketentuan pasal tersebut maka dapat dikatakan bahwa ketentuan mengenai Single Presence Policy (SPP) bagi dunia perbankan. Dalam ketentuan tersebut apbila dikaitkan ketentuan mengenai Single Presence Policy (SPP) bagi dunia perbankan tentunya bertolak belakang, di satu sisi dalam ketentuan SPP mengharapkan kepemilikan tunggal pada perbankan, namun di sisi lain ketentuan Undang-Undang Perseroan Terbatas menghendaki kepemilikan sebuah perseroan terbatas minimal dua orang atau lebih.

Ketentuan Pasal 7 ayat (5) dan (6) UU PT menyebutkan bahwa setelah perseroan memperoleh status badan hukum dan pemegang sahamnya berkurang dari dua dan jika dalam waktu paling lama enam (6) bulan wajib dialihkan sahamnya. Dalam hal jangka waktu tersebut jika perseroan belum mengalihkan sebagian besar sahamnya maka pemeggang saham bertanggung jawab secara pribadi terhadap segala kerugian yang ditimbulkannya atau pihak yang berkepentingan dapat mengajukan pembubaran melalui pengadilan negeri setempat.
Berdasarkan pemikiran tersebut di atas permasalahannya adalah bagaimanakah implementasi Single Presence Policy (SPP) bagi dunia perbankan dalam perspektif UndangUndang Nomor 40 Tahun 2007 tentang Perseroan Terbatas, dan apakah faktor-faktor yang mendukung dan menghambat penerapan Single Presence Policy (SPP) bagi dunia perbankan dalam perspektif Undang-Undang Nomor 40 Tahun 2007 tentang Perseroan Terbatas?

\section{B. Tinjauan Pustaka}

Dalam rangka mengungkap Implementasi Single Presence Policy (SPP) bagi dunia perbankan dalam perspektif Undang-Undang Nomor 40 Tahun 2007 Tentang Perseroan Terbatas, maka hukum harus dilihat dalam perspektif makro. Artinya, bekerjanya hukum harus dilihat sebagai suatu sistem yang utuh, dimana hukum itu hidup dalam suatu interaksi antara berbagai faktor pendukungnya. Lawrence Friedman mengatakan bahwa a legal system an actual operation is complex organism in which structure, substance and culture interaction (Lawrence M. Friedman, 2009: 15-18). Dari pernyaaan tersebut dapat diketahui bahwa komponen pendukung bekerjanya sistem hukum meliputi struktur, substansi dan budaya.

Komponen struktur, ialah kelembagaan yang diciptakan oleh sistem hukum itu dengan berbagai macam fungsinya dalam rangka mendukung bekerjanya sistem hukum. Dalam komponen struktur ini dikenal berbagai institusi yang bertugas sebagai pelaksana dan penegak hukum. Komponen kultur, ialah nilai-nilai yang merupakan pengikat sistem itu serta menentukan tempat sistem hukum itu di tengah-tengah kultur masyarakat secara keseluruhan. Komponen kultur akan menentukan kapan dan mengapa serta dimana masyarkat akan datang dan mentaati hukum atau justru mengabaikannya. Komponen substansi, ialah semua output dari sistem hukum. Dalam pengertian ini termasuk norma-norma, peraturan, doktrin dan sebagainya yang mengatur kehidupan masyarakat.

Menurut G.M Verryn Stuart dalam buku Malayu S.P Hasibuan yang berjudul Dasar-Dasar Perbankan, definisi bank adalah usaha yang wujudnya memuaskan keperluan orang lain, dengan memberikan kredit berupa uang yang diterimanya dari orang lain sekalipun dengan jalan mengeluarkan uang baru kertas atau logam. 
Drs.H. Malayu S.P Hasibuan sendiri memberikan definisi bank adalah lembaga keuangan, pencipta uang, pengumpul dana dan penyalur kredit, pelaksana lalu lintas pembayaran, stabilisator moneter, serta dinamisator pertumbuhan ekonomi (Malayu S.P Hasibuan, 2001 : 2).

Berbagai kerangka aturan dibuat oleh Bank Indonesia untuk merumuskan eksistensi perbankan menjadi lebih baik. Slah satunya adalah API. API merupakan kerangka dasar sistem perbangkan Indonesia yang bersifat menyeluruh dan memberikan arah, bentuk dan tatahan Industri perbankan untuk rentang waktu lima sampai sepuluh tahun ke depan. Arah kebijakan pengembangan industri perbankan di masa datang yang hendak dicapai leh API adalah untuk mencapaisuatu sistem perbankan yang sehat, kuat, dan efisien guna menciptakan kestabilan sistem keuangan dalam rangka membantu mendorong pertumbuhan ekonomi nasional.

Penyusunan Arsitektur Perbankan Indonesia (API) dirumuskan dalam enam pilar yang terdiri atas, pilar pertama, terciptanya struktur perbankan nasional yang sehat . Pilar kedua, sistim pengaturan yang efektif dan efisien. Pilar ketiga, Sistim Pengawasan Perbankan yang efektif dan independen. Pilar keempat, terciptanya industri perbankan yang kuat. Pilar kelima, tersedianya infrastruktur perbankan yang mendukung dan memadai dan pilar keenam, perlindungan terhadap konsumen. (www.bi.go.id/Arsitektur Perbankan Indonesia).

Kebijakan lain yang dikeluarkan BI untuk memperkuat struktur perbankan adalah PBI no 8/16/PBI/2006 tentang Kepemilikan Tunggal yang ditujukan untuk mewujudkan struktur perbankan yang sehat dan kuat dan merupakan salah satu faktor penting dalam mendukung efektivitas pengawasan bank. Dengan kepemilikan tunggal tersebut pelaku usaha diharuskan melakukan merger atau konsolidasi. Kepemilikan tunggal adalah suatu kondisi dimana suatu pihak hanya menjadi pemegang saham pengendali pada 1 (satu) bank. Sementara pemegang saham pengendali menurut PBI adalah badan hukum dan atau perorangan dan atau kelompok usaha yang :

1. Memiliki saham bank sebesar 25\% (dua puluh lima perseratus) atau lebih dari jumlah saham yang dikeluarkan Bank dan mempunyai hak suara.

2. Memiliki saham bank kurang dari $25 \%$ (dua puluh lima perseratus) dari jumlah saham yang dikeluarkan bank dan mempunyai hak suara namun dapat dibuktikan telah melakukan pengendalian bank baik secara langsung maupun tidak langsung.

Jadi setiap pihak hanya dapat menjadi Pemegang Saham Pengendali pada 1 (satu) bank. Dengan demikian setiap pihak yang mempunyai saham lebih dari 25\% di beberapa bank yang melakukan kegiatan usaha dengan prinsip yang sama, harus melakukan penataan kembali struktur kepemilikan perbankan sebagaimana diatur di dalam PBI No. 8/16/PBI/2006. Pelaku usaha dapat melakukan penyesuaian struktur kepemilikan sebagaimana dimaksud melalui tiga cara:

1. Mengalihkan sebagian atau seluruh kepemilikan sahamnya pada salah satu atau lebih bank yang dikendalikannya kepada pihak lain sehingga yang bersangkutan hanya menjadi Pemegang Saham Pengendali pada 1 (satu) bank;

2. Melakukan merger atau konsolidasi atas bank-bank yang dikendalikannya; atau

3. Membentuk Perusahaan Induk di Bidang Perbankan atau Bank Holding Company.

Kebijakan kepemilikan tunggal tersebut memaksa perbankan untuk melakukan pengalihan sebagian sahamnya kepada bank yang lain supaya tidak menjadi pengendali di dua bank yang melakukan kegiatan usaha yang sama, atau melakukan merger atau konsolidasi atas bank-bank yang dikendalikannya, atau membentuk perusahaan induk. Proses ini menjadi tidak berjalan secara alamiah lagi, melainkan "dipaksa" untuk menjual sahamnya atau melakukan merger atau membentuk perusahaan induk yang tidak sesuai dengan prinsip otonomi (kebebasan) yang melekat pada pelaku usaha itu sendiri.

Perseroan Terbatas merupakan bentuk usaha berbadan hukum. Perusahaan badan hukum merupakan persekutuan yang dapat menjalankan usaha dalam semua bidang perekonomian. Perusahaan badan hukum mempunyai bentuk Perseroan Terbatas (PT) dan koperasi yang dimiliki oleh pengusaha swasta, Perusahaan Umum (Perum) dan Perusahaan Perseroan (Persero) yang dimiliki oleh negara (Abdulkadir Muhammad, 2002: 47-48). Berdasarkan Pasal 1 butir 1 UUPT, 
mendefinisikan Perseroan Terbatas sebagai badan hukum yang merupakan persekutuan modal, didirikan berdasarkan perjanjian, yang melakukan kegiatan usaha dengan modal dasar yang seluruhnya terbagi dalam saham dan memenuhi persyaratan yang ditetapkan dalam undang-undang ini serta peraturan pelaksananya.

UUPT telah disahkan pada 16 Agustus 2007 dan berlaku sejak tanggal disahkan. Ini berarti Perseroan Terbatas (PT) yang ada telah ada dan yang akan ada harus tunduk pada ketentuan UUPT ini. Untuk PT yang akan didirikan, pendiriannya harus didasarkan pada ketentuan yang ada dalam UUPT, sedangkan PT yang telah ada sebelum UUPT ini disahkan harus melakukan penyesuaian anggaran dasarnya dengan ketentuan UUPT (Pasal 157 ayat 3 UUPT) dalam jangka waktu 1 (satu) tahun Terhitung setelah berlakunya UUPT ini atau tepatnya adalah sampai tanggal 16 Agustus 2008. (Tedy Padma, 2008 : 79)

\section{Metode Penelitian}

Tulisan ini termasuk ke dalam kajian hukum empiris (Lihat Soerjono Soekanto, 2006 : 51). Dilihat dari sifatnya, jenis penelitian yang digunakan penulis adalah penelitian deskriptif. (Lihat Hadari Nawawi, 1995 : 63). Jenis data yang digunakan dalam penelitan ini adalah Data Primer dan Data Sekunder. Data primer, dari hasil wawancara dengan Diana Amalia, Legal Officer Bank CIMB Niaga Cabang Surakarta dan R Arie Febrianto, Karyawan Bank Syariah Mandiri Cabang Surakarta. Sementara data sekunder adalah sejumlah keterangan atau fakta yang diperoleh dari sumber tidak langsung yang dapat memberikan keterangan tentang masalah yang diteliti, berupa literatur, dokumen, arsiparsip, dan peraturan perundang-undangan yang terkait, diantaranya berupa Undang-undang No.10 Tahun 1998 Tentang Perbankan, Undangundang No.3 Tahun 2004 Tentang Bank Indonesia, Undang-Undang Nomer 40 tahun 2007 tentang Perseroan Terbatas. PBI Nomor 8/16/PBI/2006 tentang Kepemilikan Tunggal sebagaimana diperbaiki dengan PBI Nomor 8/17/PBI/2006 tentang intensif dalam rangka konsolidasi perbankan sebagaimana telah diubah dalam Peraturan BI Nomor 9/12/PBI/2007.

Selanjutnya bahan-bahan hukum tersebut disusun secara sistematis, dikaji, kemudian ditarik kesimpulan dalam kaitannya dengan masalah yang akan dikaji. Penulisan ini bersifat deskriptif. Suatu penelitian deskriptif dimaksudkan untuk memberikan data seteliti mungkin tentang manusia, keadaan atau gejalagejala lain (Soerjono Soekanto, 2006 : 52). Teknik Analisis Data yang digunakan dalam penelitian ini adalah metode analisis interaktif (Lihat H.B.Sutopo, 2002 : 96).

\section{Hasil Penelitian Dan Pembahasan}

\section{Implementasi Single Presence Policy (SPP)}

Salah satu fungsi Bank Indonesia adalah mengatur dan mengawasi bank, maka dalam menetapkan kebijakan moneter, Bank Indonesia harus mewujudkan perbankan yang sehat dan kuat. BI kemudian mengeluarkan kebijakan Single Presence Policy (SPP) bagi bank umum di Indonesia serta kewenangan Bank Indonesia dalam Single Presence Policy (SPP). Single Presence Policy dilaksanakan berdasarkan Peraturan Bank Indonesia No. 8/16/ PBI/ 2006, dan agar dapat berjalan secara efektif dan berkelanjutan, Bank Indonesia sebagai bank sentral yang memiliki fungsi dan kewenangan mengatur dan mengawasi bank berwenang dalam menetapkan peraturan yang mendorong Single Presence Policy dan memberikan sanksi terhadap pelanggaran kebijakan tersebut. Salah satu sasaran Single Presence Policy adalah mempercepat konsolidasi perbankan sesuai API. Kebijakan Kepemilikan Tunggal mengharuskan kepada semua pemilik bank khususnya pemegang saham pengendali (PSP) untuk mengkonsolidasikan kepemilikannya di bank-bank yang dalam satu grup usahanya dengan batas waktu hingga 10 tahun.

Di dalam pelaksanaan $S P P$, bagi bankbank yang memiliki dan mengendalikan lebih dari 1 (satu) bank berdasarkan peraturan Single Presence Policy (SPP), wajib melakukan penyesuaian struktur kepemilikannya hingga tahun 2010. dalam rangka penyesuaian struktur kepemilikan ini Bank Indonesia memberikan tiga buah pilihan yaitu:

a. mengalihkan sebagian atau seluruh kepemilikanya sahamnya pada salah satu atau lebih bank yang dikendalikannya kepada pihak lain sehingga yang bersangkutan hanya menjadi pemegang sasham pengendali pada 1 (satu) bank.

b. melakukan merger atau konsolidasi atas bankbank yang dikendalikannya.

Merger adalah penggabungan 2 (dua) bank atau lebih dengan cara tetap mempertahankan berdirinya salah satu bank dan membubarkan bank-bank lainnya tanpa melikuidasi terlebih dahulu. Melalui merger dan/atau peleburan, 2 (dua) atau lebih bank akan bergabung baik 
dengan nama baru maupun tidak. Konsolidasi merupakan suatu perbuatan menggabungkan 2 (dua) atau lebih badan atau bank menjadi satu. Apabila merujuk Peraturan Pemerintah No. 28 Tahun 1999 tentang Merger, Konsolidasi, dan Akuisisi Bank, maka akibat hukum konsolidasi akan menimbulkan satu badan hukum atau bank baru dengan nama baru sedangkan merger tidak. Dengan demikian, merger dan konsolidasi memiliki pengertian yang sama, namun dalam hukum bisnis hanya berbeda pada akibat hukum yang ditimbulkan.

Menurut Diana Amalia, Legal Officer Bank CIMB Niaga Cabang Surakarta bahwa rupanya tidak semua pihak sejalan dan sepakat dengan kebijakan Single Presence Policy. Pada tingkat pelaku pasar memandang penerapan aturan tersebut dari sudut pandang kepentingan komersial. Hal ini wajar saja. Sebagai pengelola kepentingan pasar tentu harus mengedepankan kepentingan komersial. Sedangkan sebagian pihak berpendapat dalam tataran idealis, bahwa banyaknya investor asing menguasai sektor keuangan dan perbankan bisa berdampak negatif. Alhasil rencana penerapan Single Presence Policy masih menimbulkan pro dan kontra dari kalangan perbankan dan pelaku pasar. Kecenderungan pelaksanaan Single Presence Policy lebih cenderung memilih opsi merger. Menurut dia, dengan merger akan lebih mudah dari segi pengaman dan muncul bank yang kuat berskala internasional. (wawancara, 24 Oktober 2010 jam 14.00 wib)

c. Membentuk perusahaan induk di bidang perbankan (bank holding company) dengan cara:

1) Mendirikan badan hukum baru sebagai Bank Holding Company, atau

2) Menunjukkan salah satu bank yang dikendalikannya sebagai Bank Holding Company.

Untuk mendorong cepat terwujudnya SPP perbankan, maka BI memberikan paket insentif. Upaya Bank Indonesia dalam menerapkan Single Presence Policy (SPP) memberikan intensif dengan menerbitkan Peraturan BI Nomor 8/17/PBI/2006 tentang intensif dalam rangka konsolidasi perbankan sebagaimana telah diubah dalam Peraturan BI Nomor 9/12/PBI/2007. Adapun intensif yang diberikan berupa kemudahan dalam pemberian izin menjadi bank devisa, kelonggaran sementara atas kewajiban pemenuhan Giro Wajib Minimum (GWM) Rupiah, perpanjangan jangka waktu penyelesaian pelampauan Batas Maksimum Pemberian Kredit (BMPK) yang timbul sebagai akibat merger atau konsolidasi, kemudahan dalam pemberian izin pembukaan kantor cabang bank, penggantian sebagian biaya konsultan pelaksanaan due delligence, dan / atau kelonggaran sementara atas pelaksanaan beberapa ketentuan dalam Peraturan BI yang mengatur mengenai Good Corporate Governance bagi Bank Umum.

Insentif yang diberikan oleh Bank Indonesia $\mathrm{di}$ atas harus memenuhi persyaratanpersyaratan, diantaranya untuk izin bank devisa hanya berlaku dua tahun sejak berlakunya izin merger atau konsolidasi bagi bank hasil merger atau konsolidasi dengan ketentuan telah memiliki modal inti minimum Rp 100.000.000.000,00 (seratus milyar rupiah) dan peringkat komposit sekurang-kurangnya 2 (dua) dengan faktor manajemen sekurangkurangnya tiga pada dua posisi penilaian terakhir.

Kepemilikan atau pengendalian suatu bank dapat beralih kepada pihak lain melalui divestasi atau penjualan saham, baik melalui secondary offering maupun instrumen lainnya. Namun, divestasi tidak akan mencapai tujuan dari konslidasi tersebut, karena bank yang dijual tidak bubar dan jumlah bank masih tidak berkurang. Dengan divestasi, tidak terjadi sebuah konsolidsi, namun yang ada hanyalah peralihan kepemilihan atau pengendalian. Bahwa untuk opsi merger atau konsolidasi akan memberikan persoalan dilematis. Di satu sisi modal dan asset dari beberapa bank akan bersatu dan menjadi besar. Namun di sisi lainnya, upaya ini penuh resiko dan mahal. Dampak yang ditimbulkannya pun akan besar terutama dari segi ketenaga kerjaan yang kemudian berujung kepada pengangguran dan gangguan ekonomi. Sedangkan untuk pilihan Bank Holding Company dinilai menjadi jalan keluar di samping merger atau konsolidasi karena dinilai lebih murah. Dengan upaya ini, Pemegang Saham Pengendali membentuk bank induk yang hanya memiliki kegiatan sebagai holding company. Holding company tersebut mengonsolidasikan kegiatan bank-bank yang berada di bawahnya.

Kenyataan tersebut juga dikuatkan oleh $\mathrm{R}$ Arie Febrianto, Karyawan Bank Syariah Mandiri Cabang Surakarta :

"Kalau Bank Mandiri menyambut SPP dengan pilihan holding company, khususnya pendekatan yang dilakukan terhadap Bank Syariah Mandiri. Pada tahun 2008 PT Bank Mandiri 
menyuntik modal baru ke anak usahanya Bank Syariah Mandiri (BSM) senilai Rp 199,871 miliar baik dalam bentuk tunai maupun pemberian 24 unit properti melalui inbreng aktiva tetap. Penambahan modal itu dengan tujuan memperkuat struktur permodalan BSM sebagai salah satu pilar utama anak usaha Mandiri. Dari jumlah tambahan modal Rp 199,871 miliar itu yang berupa setoran modal tunai sebesar Rp 100 miliar. Selanjutnya, setoran non tunai yang dilakukan melalui inbreng aktiva tetap sebesar Rp 99,871 miliar. Setoran modal non tunai melalui inbreng aktiva tetap telah dilakukan pada 31 Desember 2008, sedangkan setoran tunai dibayarkan pada 5 Januari 2009. Bank Indonesia juga telah memberikan persetujuan atas transaksi tersebut. Dengan penambahan modal tersebut maka kepemilikan Mandiri di BSM menjadi 131.648.712 saham dengan nilai nominal Rp 5.000 sehingga seluruhnya berjumlah Rp 658,243 miliar, sekitar 100 $\%$. Angka 100 milyar juga merupakan ukuran prasyarat modal minimum bank seperti yang tertuang dalam Arsitektur Perbankan Indonesia. Bank Mandiri menambah modal untuk memperkuat bisnis BSM. Bank Mandiri menggunakan BSM untuk memperbesar pangsa di pasar ritel, terutama terhadap nasabah berpedoman syariah. Penambahan modal tersebut telah mendapatkan persetujuan dari Bank Indonesia (BI). Izin itu tertuang dalam surat nomor 10/655/ DPBI dan nomor 10/656/DPBI tertanggal 31 Desember 2008. Saat ini BSM merupakan penguasa pasar perbankan syariah di Indonesia. Hingga akhir September 2008, nilai aset BSM mencapai Rp 16,5 triliun sementara rasio kecukupan modal atau capital adequacy ratio (CAR) mereka sebesar 11,54\%. BSM menyumbang laba Rp 147,38 miliar, paling besar dibandingkan dengan anak usaha Bank Mandiri yang lain." (wawancara : 26 Oktober 2010, jam 19.00 wib)

\section{Faktor Pendukung dan Penghambat Penerapan Single Presence Policy (SPP) bagi Dunia Perbankan dalam Perspektif UU No 40 Tahun 2007 tentang Perseroan Terbatas}

Menurut Lawrence Friedman, ada tiga hal untuk mengukur faktor pelaksanaan hukum, yakni struktur, kultur dan substansi. Eksistensi ketiganya dapat dilihat dalam pembahasan berikut ini :

a. Faktor Pendukung dalam Penerapan Single Presence Policy (SPP)

Secara struktural faktor pendukung penerapan single presence policy ada pada otoritas pengelola perbankan tanah air, yakni Bank Indonesia. Era reformasi memunculkan independensi Bank Indonesia. Independensi Bank Indonesia mendorong peran aparatur Bank Indonesia dalam mengelola sistem perbankan di tanah air lebih maju. Tidak ada lagi hambatan struktural yang mengekang peran Bank Indonesia untuk mewujudkan perbankan yang sehat, kuat dan efisien. Eksistensi Bank Indonesia (BI) yang independen memudahkan bagi BI untuk merumuskan tata kelola perbankan, termasuk didalamnya adalah di dalam memantau pelaksanaan single presence policy bagi dunia perbankan. Pelaksanaan kebijakan ini dipandang perlu oleh BI dalam rangka mewujudkan struktur perbankan yang sehat dengan membenahi faktor permodalan dan memudahkan pengawasan perbankan.

Secara substansi, spirit kebijakan BI yang baru ini sebenarnya sangat baik. Bukan hanya dimaksudkan untuk mengakselerasi konsolidasi perbankan, namun lebih dari itu, mendorong penegakan prinsip tata kelola yang baik (good governance) di industri perbankan.Dengan mengintegrasikan kepemilikan saham di beberapa bank, praktik-praktik yang bertentangan dengan prinsip tata kelola yang sehat (moral hazard) tidak akan ada lagi. Akhirnya, akan tercipta persaingan yang lebih sehat di industri perbankan nasional. Merujuk pada cetak biru API, jumlah bank di Indonesia sekarang berpotensi diturunkan, yakni dari 131 bank menjadi hanya 35-50 bank.Selain melalui kebijakan single presence policy, upaya mendorong merger atau akuisisi antar bank merupakan strategi alternatif menuju konsolidasi. Hampir bisa dipastikan, para pemegang saham pengendali di bank-bank akan mulai menata kembali portofolio sahamnya dalam rangka menyesuaikan diri dengan kebijakan BI tersebut.

Secara kultur, budaya perbankan di tanah air sejak era reformasi sudah didorong sedemikian rupa untuk profesional dengan prinsip good corporate governance. Terkait dengan implementasi kebijakan single presence policy, terdapat beberapa faktor 
pendukung mengapa kebijakan tersebut sangat diperlukan. Faktor-faktor pendukung tersebut sebegai berikut :

1) Sebagai sarana meningkatkan daya saing bank BUMN

2) Sebagai sarana meningkatkan economic scale

3) Sebagai sarana untuk membatasi laju gerak penguasaan perbankan swasta yang telah dikuasai asing

b. Faktor Penghambat dalam Penerapan Single Presence Policy (SPP)

Secara struktur, penerapan kebijakan Single Presence Policy (SPP) bagi dunia perbankan tidak selamanya membawa perubahan yang positif terutama pada bank milik pemerintah. Keempat perbankan milik pemerintah (Bank Mandiri, BTN, BNI dan BRI) memiliki pangsa pasar yang berbeda-beda. BTN lebih berfokus pada pemberian kredit rumah pada kalangan masyarakat dengan tingkat ekonomi bawah. BRI lebih terfokus pada usaha kecil dan menengah serta masyarakat pedesaan. Bank Mandiri lebih berfokus pada korporasi, sedangkan fokus BNI lebih kepada masyarakat luas. Berbedanya latar belakang dan konsentrasi di tiap bank milik pemerintah menyebabkan sulit dilakukan upaya merger atau akuisisi pada bank pemerintah tersebut. Di samping berbedanya konsentrasi pada tiap-tiap bank pemerintah permasalahan penentuan penerapan Holding Company juga menimbulkan persoalan baru, artinya siapakah yang berhak menjadi bank holding, karena parameter untuk menentukanya juga belum jelas. Dari segi aset tampaknya Bank Mandirilah yang cocok untuk menjadi bank konsolidator. Tetapi hal ini tentu juga akan mendapat tantangan dari Bank BNI yang memiliki sejarah yang panjang di Indonesia. Sehingga akan terjadi adu argumentasi yang panjang mengenai siapa yang akan menjadi bank konsolidator.

Dari segi kultur, aspek batas minimal permodalan sebuah perbankan akan menimbulkan persoalan. Selama tiga puluh tahun lebih struktur perbankan begitu dimanja dengan bantuan likuiditas, sehingga upaya perwujudan struktur perbankan berdasar prinsip good corporate governace bukan menjadi prioritas. Hal ini tentu menimbulkan kekhawatiran tersendiri, mengingat sektor perbankan sangat vital bagi urat nadi ekonomi bangsa. Secara kultur perbankan tentu ini memberatkan bagi pelaku bisnis bank. Tindakan merger atau konsolidasi nampaknya sulit untuk ditempuh, sehingga pelaku bisnis bank berupa menawarkannya terhadap investor asing yang berminat di bidang perbankan emosional. Peluang emas ini tentunya banyak dimanfaatkan oleh investor asing dengan konsep liberalisasi sehingga dapat menguasai hingga 99\% saham bank. Bergesernya kepemilikan nasional ke pihak asing, dapat dilihat dari fenomena yang terjadi di perbankan nasional, diantaranya adalah investor dari negara Singapura yang menguasai saham Bank Danamon, Bank Internasional Indonesia (BII), Bank NISP, Bank Buana. Investor Malaysia menguasai saham Bank Niaga, Lippo Bank, Bank Bumiputera. Investor India menguasai saham Bank Indomonex. Investor Inggris menguasai saham Permata Bank. Investor Amerika Serikat menguasai Bank Century, sedangkan investor Jepang menguasai Bank Nusantara Parahyangan.

Contoh di Bank CIMB Niaga, sebagaimana diungkapkan oleh Diana Amalia, Legal Officer Bank CIMB Niaga Cabang Surakarta bahwa saat ini Commerce Asset Holding Berhad (CAHB) semakin memperkuat kepemilikan sahamnya di PT Bank Niaga Tbk. Kondisi itu terjadi setelah bank asal Malaysia itu menjadi pembeli mayoritas saham Bank Niaga. Kepemilikan Commerce di Bank Niaga yang dipimpin Peter B. Stok itu menjadi 56,21 persen saham. Commerce menjadi pemilik Bank Niaga setelah pada 2002 memenangi tender penjualan 51 persen saham Bank Niaga dengar harga Rp 265 per saham. Namun demikian kita tidak boleh terjebak pada istilah asing dan lokal, memang Commerce adalah investor asing, namun bukan berarti kalau dipegang investor lokal akan lebih baik, atau kalau dipegang asing berbahaya. (Wawancara, 24 Oktober 2009 jam 11.00 wib)

Implementasi Single Presence... 7 
Secara substansi, secara sistematis hambatannya sebagai berikut.

1) Benturan antara Penerapan Kebijakan Single Presence Policy dan ketentuan RUPS tahunan dan RUPS luar biasa dalam UU PT.

Pada dasarnya, sesuai ketentuan UU PT, kewenangan melakukan merger, akuisisi, atau konsolidasi berdasarkan suara pemegang saham dalam RUPS. Tujuan kebijakan SPP adalah selaras dengan PBI tentang Jumlah Modal Inti Minimum Bank Umum, yaitu untuk mengarahkan bank-bank di Indonesia agar memiliki struktur permodalan yang kuat yang salah satu caranya adalah dengan cara konsolidasi, merger, atau akuisisi. Memang tidak terdapat ketentuan yang memberikan wewenang pada BI untuk memaksa diadakannya RUPS Tahunan atau RUPS Luar Biasa, namun dengan adanya ketentuan modal inti yang harus dimiliki oleh bank menjadikan merger, konsolidasi, atau akuisisi menjadi jalan keluar yang dapat ditempuh oleh bank untuk memiliki modal inti yang telah ditentukan. Ketentuan menganai RUPS dalam UUPT bila dikaitkan dengan kebijakan Single Presence Policy (SPP) bagi dunia perbankan tentunya akan menjadi tarik menarik kepentingan, manakah dua dari ketentuan diatas yang lebih dominan atau lebih kuat posisinya. Hanya saja ada konsekuensi hukum jika bank tidak memenuhi jumlah modal inti minimum yaitu BI akan melakukan pembatasan kegiatan usaha dari bank tersebut (lihat pasal 4 PBI No. 9/16/PBI/2007). Dalam pasal 9 ayat (1) PBI No. 8/16/PBI/2006 yang menyatakan bahwa pemegang saham pengendali yang tidak melakukan penyesuaian struktur kepemilikan dalam jangka waktu yang telah ditetapkan dilarang melakukan pengendalian dan dilarang memiliki saham dengan hak suara pada masing-masing bank lebih dari $10 \%$ dari jumlah saham bank. Sehingga, pemegang saham pengendali harus menyesuaikan struktur kepemilikannya baik dengan cara merger, akuisisi, atau konsolidasi dan yang terpenting pemegang saham pengendalinya tunggal

2) Tidak Berpihaknya PBI Kepemilikan Tunggal Perbankan Indonesia terhadap Pemegang Saham Minoritas. Hak yang dapat diperoleh setiap pemegang saham agar sahamnya dapat dibeli dengan harga yang wajar jika tidak menyetujui diantaranya adalah proses Penggabungan, Peleburan, Pengambil-alihan, dan Pemisahan (Pasal 62) dan jumlahnya tidak melebihi $10 \%$ (sepuluh perseratus) dari jumlah modal yang ditempatkan dalam Perseroan (Pasal 37 ayat (1) huruf b). Ketentuan tentang divestasi, merger atau konsolidasi tetap harus memperhatikan kepentingan stakeholder yang nampaknya terabaikan dalam Peraturan BI Nomor 8/16/PBI/2006 tanggal 5 Oktober 2006 tentang Kepemilikan Tunggal Perbankan Indonesia.

3) Problematik Holding Company dalam Perbankan

Opsi ketiga yang ditawarkan oleh Bank Indonesia adalah pembentukan Bank Holding Company. Pengertian holding company dalam khazanah hukum Indonesia tidak diatur secara tegas, akan tetapi di dalam praktis bisnis para konglomerasi telah mengenalnya. Namun muncul persoalan mendasar terkait pilihan Holding Company ini. Memang berdasarkan pertimbangan ekonomi opsi membentuk Bank Holding Company dirasakan paling tepat. Namun demikian UU PT kita belum memberikan ruang yang memadai bagi eksistensi Holding Company, apalagi jika harus mengakomodasi kebutuhan pelaksanaan kebijakan Single Presence Policy (SPP).

Apabila tiga persoalan (struktur, kultur dan substansi) tersebut di atas belum teratasi maka penerapan Single Presence Policy (SPP) bagi dunia 
perbankan akan menimbulkan dampak sebagai berikut.

1) Single Presence Policy Dikhawatirkan Menyebabkan Ketidakadilan

Pemerintah sebagai salah satu otoritas struktur hukum dan pemangku kepentingan tentu pada posisi ingin mempertahankan eksistensi kesemua bank pemerintah. Namun, bank milik pemerintah tidak semuanya berada padaa posisi dan kondisi yang sama. Di antara keempat bank milik pemerintah terdapat bank yang memeiliki permodalan besar dan sebaliknya, dan juga dari kempat bank milik pemerintah tersebut memiliki fokus bisnis yang berbeda pula. Penyatuan keempat bank BUMN menjadi satu akan menyebabkan ketidakadilan. Hal ini dikarenakan masing-masing bank berkeinginan untuk menjadi bank tunggal. Meskipun rumor bisnis sampai saat ini masih memenangkan bank Mandiri sebagai pengakuisisi.

2) Persoalan Ketenagakerjaan

Dari segi kultur perbankan yang saat ini terbentuk, penerapan Single Presence Policy (SPP) bagi dunia perbankan berdampak pada bank umum konvensional muapun bank milik pemerintah terkait dengan ketenagakerjaan. Dengan diberlakukanya kebijakan kepemilikan tunggal tentu akan mucul permaslahan dibidang ketenagakerjaan. Jika terjadi merger, maka kemungkinan besar akan terjadi efisiensi pula dalam ketenagakerjaan.

3) Persoalan Kepemilikan Dalam penerapan kebijakan Single Presence Policy (SPP) bagi dunia perbankan terdapat permasalahan yang terkait dengan kepemilikan bank tersebut. Terdapat dua permasalahan, pertama yaitu penentuan pihak yang menjadi pemegang saham pengendali (PSP). Dalam penentuan pihak yang menjadi pemegang saham pengendali bank terdapat dua jenis, pertama yang disebut legal owner pemilik yang tercatat secara hukum) dan beneficial (pihak yang menikmati manfaat ekonomis dari benda yang dimiliki oleh legal owner. Dalam hal ini hubungan hukum antara legal owner dengan beneficial owner sulit dilakukan karena terkait konsekuensi tangung jawab para pihak. Masalah kedua adalah mengenai kepengurusan. Dalam penerapan kebijakan Single Presence Policy (SPP) bagi dunia perbankan, belum terdapat format yang cocok dan tepat untuk hal kepengurusan sesuai dengan ketiga opsi yang ditawarkan dalam rangka penerapan Single Presence Policy $(S P P)$ bagi dunia perbankan. Permasalahan yang ketiga adalah pilihan yang ideal dari ketia opsi yang ditawarkan dalam Single Presence Policy (SPP) bagi dunia perbankan, karena dari ketiga opsi tersebut terdapat kelemahan dan kelebihanya.

\section{E. Simpulan}

Kebijakan SPP dilaksanakan berdasarkan Peraturan Bank Indonesia No. 8/16/ PBI/ 2006, dan agar dapat berjalan secara efektif dan berkelanjutan, Bank Indonesia sebagai bank sentral yang memiliki fungsi dan kewenangan mengatur dan mengawasi bank berwenang dalam menetapkan peraturan yang mendorong $S P P$ dan memberikan sanksi terhadap pelanggaran kebijakan tersebut. Salah satu sasaran SPP adalah mempercepat konsolidasi perbankan sesuai API. Kebijakan Kepemilikan Tunggal mengharuskan kepada senua pemilik bank khususnya pemegang saham pengendali untuk mengkonsolidasikan kepemilikannya di bankbank yang dalam satu grup usahanya dengan batas waktu hingga 10 tahun. Bagi bank-bank yang memiliki dan mengendalikan lebih dari 1 (satu) bank berdasarkan peraturan $S P P$, wajib melakukan penyesuaian struktur kepemilikannya. Dalam rangka penyesuaian struktur kepemilikan ini Bank Indonesia memberikan 3 (tiga) buah pilihan yaitu : Pertama, mengalihkan sebagian atau seluruh kepemilikanya sahamnya pada salah satu atau lebih bank yang dikendalikannya kepada pihak lain. Kedua, melakukan merger atau konsolidasi 
atas bank-bank yang dikendalikannya. Ketiga, Membentuk perusahaan induk di bidang perbankan (bank holding company) dengan cara mendirikan badan hukum baru sebagai Bank Holding Company atau menunjukkan salah satu bank yang dikendalikannya sebagai Bank Holding Company.

Faktor pendukung dalam penerapan SPP bagi dunia perbankan bahwa SPP merupakan sarana untuk meningkatkan daya saing bank BUMN, sarana untuk meningkatkan skala ekonomi dan sarana untuk membatasi penguasaan bank swasta oleh pemilik asing. Faktor penghambat penerapan $S P P$ bagi dunia perbankan dalam perspektif UUPT tentang Perseroan Terbatas meliputi hambatan struktural, kultural dan substansi. Hambatan struktural dan kultural meliputi dua hal yaitu ; eksistensi bank BUMN yang tidak fokus sehingga menimbulkan persaingan yang tidak sehat antara keemapat bank BUMN tersebut dan masuknya investor asing yang akan mengurangi daya saing dan keberanian pemain perbankan dalam negeri. DIsamping itu ada beberapa penghambat substansi, yaitu : Benturan antara penerapan kebijakan Single Presence Policy dengan ketentuan RUPS tahunan dan RUPS luar biasa dalam UUPT, tidak Berpihaknya Peraturan BI Nomor 8/16/PBI/2006 tentang Kepemilikan Tunggal Perbankan Indonesia terhadap pemegang saham minoritas dan persoalan payung hukum Holding Company dalam Perbankan yang belum siap.

\section{F. Saran}

1. Bank Indonesia, Pemerintah dan Dewan Perwakilan Rakyat perlu melakukan sinkronisasi peraturan yang terkait dengan penerapan PBI Nomor 8/16/PBI/2006 tentang Kepemilikan Tunggal Perbankan Indonesia dengan UUPT, terutama terkait dengan pemegang saham minoritas dan Rapat Umum Pemegang Saham.

2. Bank Indonesia perlu memberikan perlakuan khusus terkait PBI Nomor 8/16/PBI/2006 tentang Kepemilikan Tunggal Perbankan Indonesia terhadap bank milik pemerintah.

3. Bank Indonesia perlu melakukan antisipasi penerapan PBI Nomor 8/16/PBI/2006 tentang Kepemilikan Tunggal Perbankan Indonesia terkait dengan permasalahan ketenagakerjaan terutama dengan opsi merger atau diakuisisinya bank yang terkena pemberlakukan peraturan tersebut. 


\section{Daftar Pustaka}

Abdulkadir Muhammad. 2002. Hukum Perusahaan Indonesia. Bandung: PT Citra Aditya Bakti.

Johanes Ibrahim. 2008. "Penerapan Singgle Presence Policy dan Dampaknya bagi Perbankan Nasional”. Jurnal Hukum Bisnis.No. 6 Tahun VII

Hadari Nawawi. 1995. Metode Penelitian Bidang Sosial. Yogyakarta: UGM-Press

HB. Soetopo. 2002. Pengantar Metodologi Penelitian Kualitatif. Surakarta: UNS Press.

Lawrence M. Friedman. 2009. Sistem Hukum Perspektif Ilmu Sosial. Jakarta: Nusa Media. (terjemahan)

Malayu S P Hasibuan. 2005. Dasar-Dasar Perbankan di Indonesia. Jakarta: Bumi Aksara

Soerjono Soekanto. 2006. Pengantar Penelitian Hukum. Jakarta: UI Press

Tedy Padma Kwardiano. 2008. Masalah diseputar penyesuain AD PT Menurut UU No 40 tahun 2007, Makalah dalam jurnal hukum bisnis.

www.bi.go.id/Arsitektur Perbankan Indonesia. (24 Oktober 2010) 